\title{
Protecting National Assets against Information Operations in Post-modern World
}

\author{
Juha K Mattila \\ Aalto University \\ Finland \\ juhakaimattila24@gmail.com
}

\begin{abstract}
Nations may defend their freedom of Information and availability of their Information and Communications Technology Services by either Isolation or Habituation, which are both applicable but require totally different structures, culture and governance. Information Operations are not only state level measures, but can be utilized at very low levels and by small entities. It requires multilevel preparations of defence executed together in public-private-voluntary sector alliance extending over national borders. Unlike conventional military operations information operations are ongoing at strategic, operational and tactical levels even in peace time.
\end{abstract}

Information operations, National defence, Cyber operations, Post-modern confrontations.

\section{INTRODUCTION}

This paper introduces general model for information operations between states and discusses two main strategies of defence in information era. A general structure of means in Information Operation is defined as a starting point. These means are included in general model of confrontation between states. Two scenarios of defence is being discussed within the orientation of a general confrontation model. Defence in Information Age may follow two strategies of Isolation or Habituation. These strategies are further illustrated by referring to their prominent applicants.

\section{MEANS OF INFORMATION OPERATIONS}

Most classical Information Operations (Mattila 2003) lines of effect are physical means, electro-magnetic means, cyber or computer system means and psychological means as depicted in fig. 1.

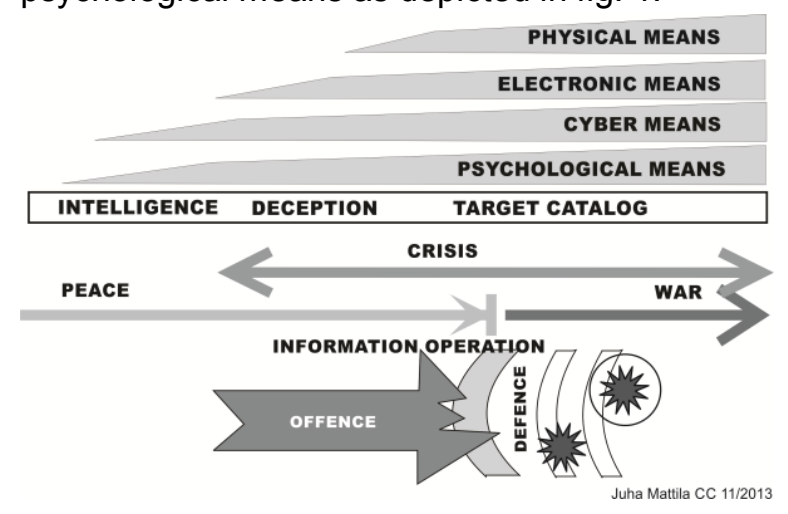

Figure 1: Classical structure of Information Operations

These means of effect are supported by intelligence, deception, targeting, training and logistics. Postmodern space of operation does not see the clear line between peace and war, thus there is always a grey area in between. Information Operations are not restricted in war time only. They are waged as a part of political, socio-economical or financial confrontation, which is ongoing between states with differing interests (Mattila 2013). Information Operations are not linear, nor are they attrition in nature, but they are utilized in full spectrum and widely in post-modern area of operation. They are not symmetric, but planned to utilize as much asymmetric advantages as possible. Some Chinese military analysts call this "Unrestricted Warfare" (Qiao \& Wang 1999).

\section{CONFRONTATION AT NATIONAL LEVEL INFORMATION OPERATIONS}

In his basic confrontation model of two entities, blue and red, Clausewitz (1874) has defined three bases of ability (sometimes they are also centers of gravity) as shown in fig. 2: (1) population of the society, (2) power of the governance of the society and (3) force that the society is able to harness to defend against adversary's force projection and counter-attacks. 


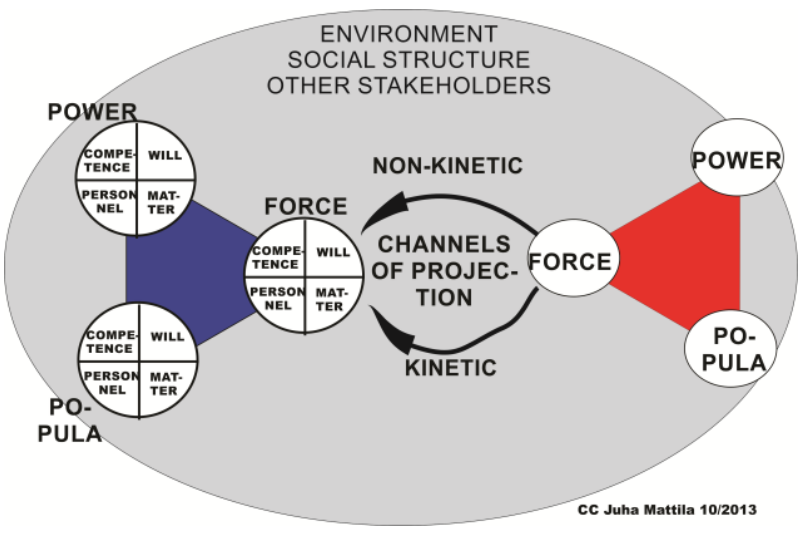

Figure 2: Confrontation model between two states

Each of these three bases could be defined as a construction of personnel and matter. Personnel and matter do form interactive system that follows procedures. The effect of this system is measured not only by its volume as in Lanchester's (MacKay 2005) combat equations, but also by quality of their will, competence, trust and usability. Model simplifies these to the four components: Personnel, Competence, Matter and Will. The Clausewitzian interdependent structure of three bases is able to project force as example in NATO Comprehensive Approach (Wendling) via multiple channels to create either kinetic or non-kinetic effects in adversary's physical, information or cognitive levels as defined in Effect Based Operations (Smith 2003) concept. These three interconnected bases could be taken as basic elements in all military, social, economy or political structures.

There are other stakeholders or parties that can be used as "hired" 3rd party or "neutral" but distorting forces in the area of information operations. States may deny using cyber means, but blame private "hactivists" for launching attacks like in situation of Bronze soldier between Russia and Estonia 2007 (Wikipedia 2013). Media can publish biased information like in situation, when Al Jazeera published old video footage as live on Egypt situation during summer 2013 (UPI 2013). National organizations may establish their computer network operations capabilities in distributed way all over the Internet thus achieving force projection capability that is screened by anonymity like in alleged NorthKorean operation "Dark Seoul" against SouthKorean information service assets (Symantec 2013).

Information operation can have effect on material assets as in Stuxnet -malevolent software attack against Iranian plutonium production program (Telegraph 2012). Information may change the will of population in home front, have secondary effect on political decision making, which again effects military arms utilization in conventional area of operation. This happened in Vietnam War, where Vietcong Tet-operation was military failure, but originated video footage. Videos published in U.S. television channels changed the public opinion about Vietnam War thus altering political decision making (Mattila 2003). The Arab Spring movement was triggered by tragic news of Tunisian vegetable vendor driven to self-immolation. This was told at same time with stories of ruler's luxurious lifestyle. The strong feeling of unjust and revolutionary spirit was carried on and amplified by social media and mobile phone messaging through North-African Arabic speaking nations and originated The Arab Spring movement fall 2011 (Rand 2013).

\section{NATIONAL INFORMATION OPERATION DEFENCE STRATEGIES}

In Information operations defence is the main strategy against any offensive information operations unless there are capabilities of countering threat with other means, which are explained in chapter $\mathrm{C}$. This is due the wide variety of means and full spectrum action of information operations (Mattila 2013). As post-modern societies are increasingly dependent on information and interrelationships between states are much more complex than earlier, there are two main methods to prepare defensive capabilities: Isolation or Habituation as defined in fig. 3.
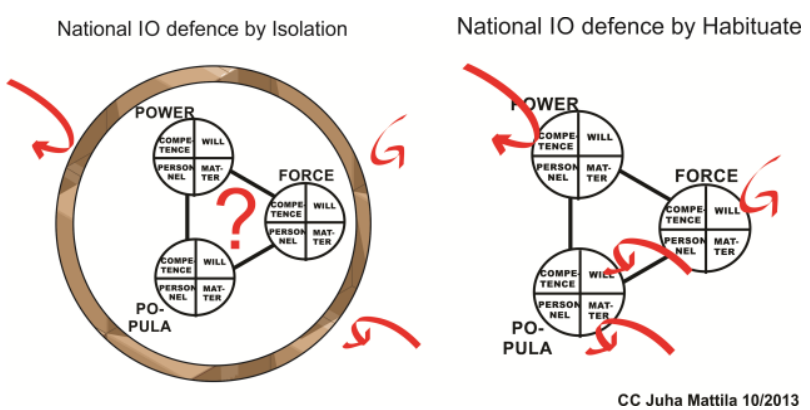

Figure 3: Example of Information Operation strategies for national defence

Isolation is following more traditional methods of defining national borders in all dimensions and building ability to shut all avenues from foreign force projection with filtering or protecting gateways like customs, monetary hubs, governmental monopolies, firewalls, etc. Habituation is more networked method of accepting dependencies and vulnerabilities, but exposing all three bases of nation to every day malevolent effects, thus habituating all instances to endure or shelter when facing attacks. It includes also building relationships to extend defensive network in all aspects of international co-operation.

Since both strategies require strong centralized effect on citizen's private behaviour with information and governance on private sector 
information utilization, it is useful to refer each utilized strategy from human rights point of view. For this purpose International Human Rights Rank Indicator was chosen to give relational reference. Although ranking information is produced by NonGovernmental Organization (GNFRAD 2013), it is still relational and utilized in this context only to give feeling of this approach.

As strategies are relative to situation, resources and goals, a class of hybrid strategy is also presented with some examples. This is to express that defence in information operations, whether it is using physical, electromagnetic, cyber or psychological means is always relative to each nation's and its potential adversaries relationship and situation.

\subsection{Isolation Strategy}

China has been following mainly the isolation strategy. Chinese government is protecting their information assets and citizens from computer network attacks and international information sources by creating the "Great Fire Wall" to filter all connections and content over national boundaries and establishing national social media services, mobile access, etc. The People's Republic of China proclaims (Smith\&Cohen 2013) that:

\section{"within Chinese territory the Internet is under the jurisdiction of Chinese sovereignty. The Internet sovereignty of China should be respected and protected."}

There have been also doubts that Chinese officials have hired a vast number of "online commenters" to promote "official" content and the Communist Party. This outer perimeter defence often neglects inner structure weaknesses, but China, as a big unified information and online market, has also been able to get rights to produce their national version of Microsoft Operation System and copied Cisco IOS-program thus being able to safeguard their basic Internet-structure inside as well as outside (Clarke\&Knake 2010). China is also empowering strong governmental control over their specific language domain with government owned media, energy and finance enterprises. China is ranked as 48th in International Human Rights statistics (IHHRI 2013).

The Islamic Republic of Iran is also utilizing isolation strategy by building a "Halal internet". Iranian YouTube equivalent Mehr was launched on December 2012 with only government-approved videos (Smith\&Cohen 2013). It is believed that national "Halal internet" grows gradually as more content and services from global Internet is being blocked. Together with Farsi language this approach will provide good border control over cyber and propaganda attacks from outside against
Iran and Iranian people. There is no information on, how well Iranian network operators, broadcasters and citizens are protected against malevolent information and attacks launched within the nation. Iran has also strong control over media and publication entities within their special language domain together with national energy, telecommunications and finance companies. Iran is ranked as 168th in international Human Rights statistics (IHHRI 2013).

North Korea is utilizing its isolation and difference as asymmetric advantage over their assumed adversaries. Information security vendors have claimed that North Korea has been waging computer network attack against South Korea, Japan and USA for last four years (Symantec 2013). Since North Korean own digitalization degree is very low compared to its neighbour, vulnerability for computer network attacks is diminutive and state propaganda seems to have very strong grip of in-state information and they are amongst 10 nations that least respects human rights (IHHRI 2013)). North Korea may be taken one often least vulnerable countries to outside Information attacks. They have built strong computer network attack arm, which is launching information offensives and utilizing every weakness of their more open adversaries. They infiltrate to information systems, inject malware in critical points utilizing zero day vulnerabilities and activate effects simultaneously like it was done on 20th of March 2013, when South Korean bank and media outlets were jammed and about 32000 computers boot records were wiped out (Symantec 2013).

\subsection{Habituation Strategy}

Sweden, as a small but thoroughly digitized nation, is utilizing the Habituation strategy. While being 2nd in International Human Rights Rank Indicator (IHHRI 2013), Sweden has strong screening of all Internet and telephone content passing through their borders executed by Forsvarets Radio Anstalt (Datainspect 2013). Swedish government do not isolate their citizens, network service providers or private sector in any governmental driven way. With exposure to ongoing Internet malevolence they (1) harden their information sources, services and users; (2) build culture for citizens to recognize misinformation by exposing them to different types of propaganda; (3) utilize modern methods of cloud computing, information assurance and mobile access; (4) empower public and private partnership networks to counter existing malevolent features in Internet. This can be seen in Global virus Map, where Sweden is one of least infected but most networked nation in Europe (McAfee 2013). Although democratic society with open market economy, Sweden has required its private sector to be ready to counter attacks by setting legal 
obligations to enterprises (Swedish 2013)). Sweden is also networked with other nations including integrated energy grid with other Nordic countries and EU, a member of EU, a member of European Government CERT group and a Partner for Peace with NATO.

\subsection{Hybrid Strategies}

U.S. Military has analysed that they cannot protect vast U.S. private sector functions, global media industry nor their finance sector, which are very Internet dependent but not that controlled at federal level. They focus on building international structure of connection and content surveillance parallel with pre-emptive computer network attack capabilities, which ensure strategic superiority in cyberspace (Clarke\&Knake 2010). This strategy is very symmetric when declaring that any information offensive will be countered with superior computer network attack supported with UAV's at physical domain if needed. Otherwise U.S.A. is very dominant in English language domain with vast entertainment, media and content industry. U.S. industry utilizes Internet and other avenues to their whole extent. United States is ranked as 21st in international Human Rights statistics (IHHRI 2013).

Russian defence strategy is declaring that any defined Information Attack will be countered by nuclear strike (National Security 2000). This is asymmetric way to utilize Cold War era threshold approach, that any threat will be countered with nuclear devastation, which might be a sign that other protective measures were not sufficient in early 2000 (Russian Military 2010). In some scenarios this threat with nuclear escalation may be called as bluff and be utilized against them. Besides this threshold Russian has very effective organization called FAPSI (Federal'naya Agenstvo Pravitel'stvennoy Svayazi i Informatsii), that is both developing information operation arms and protecting national structures within it task to collect information pertaining to

"political, economic, military, science and technology through use of electronic means" (Legislative Act 1995).

FAPSI is also providing safe communications and information services to Russian government thus securing information utilization for governing base of Clausewitzian tripod. Citizens are informed by government owned or controlled media within Russian speaking domain. Russian Federation is ranked as 46th in international Human Rights statistics (IHHRI 2013).

\section{DISCUSSION}

Information operations defence strategies Isolation and Habituation and their hybrid utilization are currently utilized globally as examples define. There is no single better strategy, since strategy is always relative to each society's situation, resources and confrontation scenario. Isolation requires strong and coherent control over all three components of society. Most often this is very centralized and thus center of gravity and goal to adversary. Isolation often leaves inner structure quite vulnerable since resources are focused in defence of outer perimeter. This is very vulnerable to insider and man-in-the-middle attacks. To prevent this society should be really homogenized and unified, or there is pervasive monitoring structure within population, governance and force, which is utilized with severe sanction procedure.

Habituation requires high education, awareness and coherent spirit from society, governance and force. Both governance and force projection abilities are dependent on shared awareness and ability to function in small teams or individually. This is center of gravity and thus target for adversary's offensive means. Society should also be willing to endure hardship in normal life during crisis time based on logical reasoning. This ability is gradually vanishing from economically wellbeing and individualistic societies.

\section{CONCLUSION}

This paper has defined a new approach to study Information Operations Defence strategies by fusing Clausewitzian tripod center of gravity structure to post-modern globalized interrelationships and having confrontation using current means of Information Operation. This model provides bases for further studies of Isolation or Habituation strategies and their hybrid utilization in each national situation. Since model includes confrontation dimension it avoids the unfortunate one sided strategic view. Bipolar confrontation simplification is also avoided by introducing more complex interrelation system between stakeholders of crisis. 


\section{REFERENCES}

Mattila, Juha K. (2003) Information operations in recent military clashes and threat analysis of postmodern commerce. Originally published in Finnish: Informaatio-operaatiot viimeaikaisissa sodissa ja kehittyvan uhkakuvan merkitys suomalaisen liiketoiminnan turvaamiselle. 29.9.2003. ISBN 951-42-7122-X

Mattila, Juha K. (2013) Basics of Information Operations 1/4. Unpublished blog writing http://c4isys.blogspot.ae/2013/10/basics-ofinformation-operations.html. (27.10.2013)

Qiao Liang \& Wang Xiangsui (1999): Unrestricted Warfare - Assumptions on War and Tactics in the Age of Globalization. U.S. Embassy translation from November 1999. http://www.fas.org/nuke/guide/china/doctrine/unr esw1.htm (28.11.2013)

Clausewitz, Carl von (1874): On War. Translated by J.J. Graham 1874.

MacKay, Nial (2005), Lanchester combat models. University of New York, May 2005. Cornell UniversityLibrary arXiv.org>math>arXiv:math/0606300

Wendling,C. The Comprehensive approach to civilmilitary crisis management. IRSEM Reports

Smith, Edward A. (2003), Effects-Based Operations. CCRP Publications 2003

Wikipedia, 2007 cyberattacks on Estonia. http://en.wikipedia.org/wiki/2007_cyberattacks_o n_Estonia (28.11.2013)

UPI, July 10, 2013: Al Jazeera staff resign. http://www.upi.com/Top_News/World-

News/2013/07/10/AI-Jazeera-staff-resign/UPI45651373456029/ (28.11.2013)

DarkSeoul -operation exposed by Symantec, McAffee and Kabersky Lab. See details from http://www.symantec.com/connect/blogs/fouryears-darkseoul-cyberattacks-against-southkorea-continue-anniversary-korean-war (28.11.2013)

The Telegraph 01 Jun 2012, Barack Obama ordered Stuxnet cyber attack on Iran. http://www.telegraph.co.uk/technology/news/930 5704/Barack-Obama-ordered-Stuxnet-cyberattack-on-Iran.html (28.11.2013)

Rand, Dafna H. (2013), Roots of the Arab Spring. University of Pennsylvania Press June 2013

GNFRAD (2013), Global Network For Rights And Development publishes International Human Rights Rank Indicator by evaluating 21 variables and normalizing them to one rate indicator. Information gathering is subjective as always in international sosio-political research.(28.11.2013)

Smith E. \& Cohen J. (2013): The New Digital Age. Reshaping the future of people, nations and business. John Murray, London

Clarke, Richard A. \& Knake, Robert K. (2010): Cyber War, The next threat to national security and what to do about it. Harper-Collins Publishers, New York. Page 55.

IHHRI report. http://ihrri.com/index.php (17.10.2013)

Datainspectionen's paper to FRA on 29.05.2013 http://www.fra.se/download/18.17ed2a0913b913 44b7b8000144/301555.pdf (28.11.2013)

McAfee virus info (2013), http://home.mcafee.com/virusinfo/global-virusmap for up-to-date commercial malevolent software statistics (28.11.2013)

Swedish Civil Contingencies Agency. See pages http://www.msb.se/en/ (28.11.2013)

National Security Concept of Russian Federation, January 2000

Russian Military Politics and Russia's 2010 Defense Doctrine. Edited by Stephen J. Blank

Legislative Act by Russian President 3 July 1995 No 662 